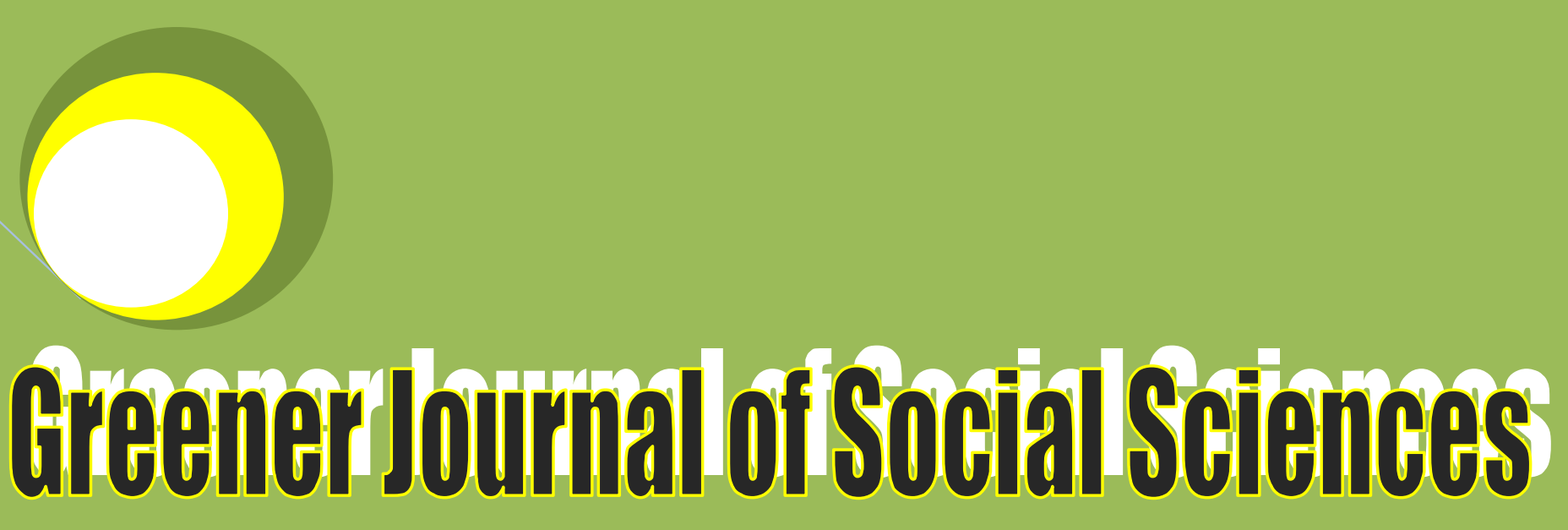

ISSN: 2276-7800 ICV: 5.99

Submitted: $22 / 11 / 2017$

Accepted: 29/11/2017

Published: 23/12/2017

DOI: http://doi.org/10.15580/GJSS.2017.5.112217173

The need for an efficient Integrated Data

Management (IDM) system in boosting

economic opportunities

in Nigeria: Empirical evidence from Edo state

By

Muhammed A. Obomeghie (Ph.D) Andrew O. Bello Abubakar Idris 


\title{
The need for an efficient Integrated Data Management (IDM) system in boosting economic opportunities in Nigeria: Empirical evidence from Edo state
}

\section{${ }^{*}$ Muhammed A. Obomeghie (Ph.D), ${ }^{1}$ Andrew O. Bello and ${ }^{2}$ Abubakar Idris}

Department of Statistics, Auchi Polytechnic, Auchi. Edo State, Nigeria.

E-mails: 'belloao2002@ yahoo.com, ${ }^{2}$ idrisbakr@ yahoo.com

${ }^{*}$ Corresponding Author's E-mail: maoisdg@ yahoo. com

\begin{abstract}
The rational for this work is to present a statistical analysis of the need for an Integrated Data Management (IDM) system that will help in boosting economic opportunities in Nigeria. The rational for the study stems from the fact that researchers have observed that the state of data management in Nigeria have not translated adequately into increased economic opportunities. A field survey design is adopted in the study covering randomly selected business outfits in Edo State. A sample size of two hundred respondents of various businesses in Edo State was used. A structured questionnaire was used in data collection. The chi-square test is used in analyzing the collected data. Findings show that there is the need for a country-wide intergraded management to further boost economic opportunities. It is recommended that Nigeria should as a matter of urgency set-up an efficient integrated data management (IDM) system that will serve as a pivotal point for research and other scholarly output that will lead to more economic opportunities for Nigerians.
\end{abstract}

Key words; Integrated, efficiency, Data management, Economic opportunities Metadata.

\section{INTRODUCTION}

The need to efficiently manage data in Nigeria has become imperative given a plethora of advantages a prudent data management in an economy bestows on the economic activities in the country which includes, operating efficiency and effective client relationship in business, accurate marketing strategies, better risk management, government compliance regulations etc.

Data quality is now fundamental to navigating an ever more complex business environment, one in which the ability to engage with customers with relevance and consistency across multiple channels is fast becoming a key business imperative. [1]

The benefits of an efficiently managed, trustworthy data and the problems associated with poor quality data has been a constant attraction in economic opportunities for developing countries. This is further underscored by the fact that, as data volume rapidly expand and data environment become more complex what used to be inconsequential data discuss has evolved into a massive country - wide problem. In a study by [2] it was observed that, data is a valuable and strategic asset for financial institutions because it not only helps the organization meet complain requirements but it can help gain deep insight into customer behavior and in making critical business decision.

Studies have shown that in most developing countries data management has been a great challenge.[3]. This is mostly due to the complexities associated with data management which is due partly to the fact that multiple economic and business group such as risk managers, operations managers, trading and compliance agencies view the same information differently, this can lead to material dispute about the quality of data, definitions, information storage etc.

A study by [4], observed that the reason why data management in developing countries have failed to perform its cardinal role includes: 
- Great diversity of data type and quality

-Complex and chaotic nature of data development

-Outputs not linked to data

-Supporting documents not situated with the data file

-Little use of metadata to support future use

-Immature understanding of benefits of sharing and this need for management

-Limited understanding of the barriers to opportunities for information sharing and re-use.

This study is organized as follows; section one is the introduction, section two looks at the concept of data management, section three takes care of the theoretical models of the study, section four is made up of the material and methods of the study while finally section five is made up of the data analysis and conclusion of the study

\section{Concept of data management}

Data management has been defined as the development, execution and supervision of plans, policies, programs and practices that control, protect, deliver and enhance the value of data and information assets. [5]

Equally, an online article [6] defines data management as the development and execution of architecture, policies, practices and procedures in order to manage the information lifecycle needs of an enterprise in an effective manner.

Supporting the view of other scholars on the merit of operating an integrated data management system, it was discovered that an efficient IDM ensures the provision of correct information to the right person(s) at the necessary time. [7]. As a subset of information, management, it addresses awareness, access and delivery of information. This management area includes the safeguarding compilation, cataloguing, storage, distribution and retrieval of data. Planners and decision-makers use information taken from data bases, web pages, and files to determine future action.

\section{Statisticians' role in data management}

The role of the statistician in data management in any economy is diverse, challenging and profound for the good health and increase opportunities in that economy. While it is agreed that traditional role of the statistician is to scientifically collate, analyses, store, share, present and interpret numerical data as well as processing such data into useful information. However, a recent research stressed that successful statisticians need to possess many qualities required in today's fast changing economic and business environment such as collaboration, diplomacy, written and oral skills and an ability to be responsive; they are also knowledgeable when debating strategy and analytical techniques.[8] However, increasing data transparency will require statisticians to evolve and learn new skills and behaviors during their career which may not have been an accepted part of the traditional role. Statisticians will move from being the gate-keeper of data to be data facilitators. To adapt successfully to this new environment, the role of the statistician is likely to be broader, including defining new responsibilities that lie beyond the boundaries of the traditional role. Statisticians should understand how data transparency can benefit them and the potential strategic advantage it can bring and be fully aware of the economic and business commitments to data transparency and the policies within their company or research institute in addition to focusing on reviewing requests and provisioning data.

Data transparency will evolve the role of statisticians within the economic environment, academia and research bodies to a level which may not have been an accepted part of their traditional role or career. In the future, skills will be required to manage challenges arising from data sharing; statistician will need strong scientific and statistical guiding principles for re-analysis and supplementary analyses based on researchers' requests, have enhanced consultancy skills, in particular the ability to defend good statistical practice in the face of criticism and the ability to critique methods of analysis. Statisticians will also require expertise in data privacy regulations, data redaction and anonymisation and be able to assess the probability of re-identification, an ability to understand analyses conducted by researchers and recognize why such analyses may propose different results compared to the original analyses. Bringing these skills to the implementation of data sharing and interpretation and the results will help to maximize the value of shared data while guarding against misleading conclusions.

It was asserted further that statisticians are ambassadors for data sharing and are central to its success.[8] They play an integral role in data sharing discussions within their respective companies and also externally helping to shape policy and process while providing input into practical solutions to aid data sharing. Secondary use of data is implicit in public-sector trials and access to data is aligned with the values of many pharmaceutical and biotechnology companies related to benefits to society and patients; some companies and individuals remain cautious regarding the 
benefits and skeptical of how the data will be used in particular where there is the potential to make unfounded health scares involving their assets.

Statisticians possess many qualities such as negotiation, collaboration, diplomacy, written and oral skills and an ability to be responsive and knowledgeable when debating analytical techniques; however data transparency will require the majority of statisticians from industry to learn new skills and ways of working. If not already engaged with external activities, statisticians within the economic, business and academia will increasingly expand their role to become more embedded in the data facilitation process. To adapt successfully to this new environment, statistical leaders within the Economic, business and academia will work towards broadening the role of the statistician, and define new responsibilities that lie beyond the normal boundaries. Building trust with the public through greater transparency and increased engagement with academic researchers will bring many benefits, but these will inevitably come at a cost in terms of time and resources, which will be particularly acute for smaller companies, and will require commitment from industry leaders to address these demands.[8].

The Nigeria economic environment is bedeviled by poor data management which have in-turn hindered both government and private enterprise in formulating accurate policies in the past. If and when a reliable CIDM system is in place opportunities will abound in the following areas;

-Industrial efficiency:

-Enhancing Customer Satisfaction:

-Adopting more informed decision:

-Government Planning:

-Single view of customers:

-Customer profiling:

\section{Theoretical models of data management}

There are a number of data management models both in the business enterprises and in government enterprises with different strategic approaches however the maturity model will be best adaptable to the Nigeria context. Among other models, the maturity model provide a common language and framework depicting what progress looks like in all the fundamental discipline of data management and offers a gradated path to improvement which is easily tailored to an organization's strategy, strength and priorities.[9]. This is shown in Fig 1.1. below; 


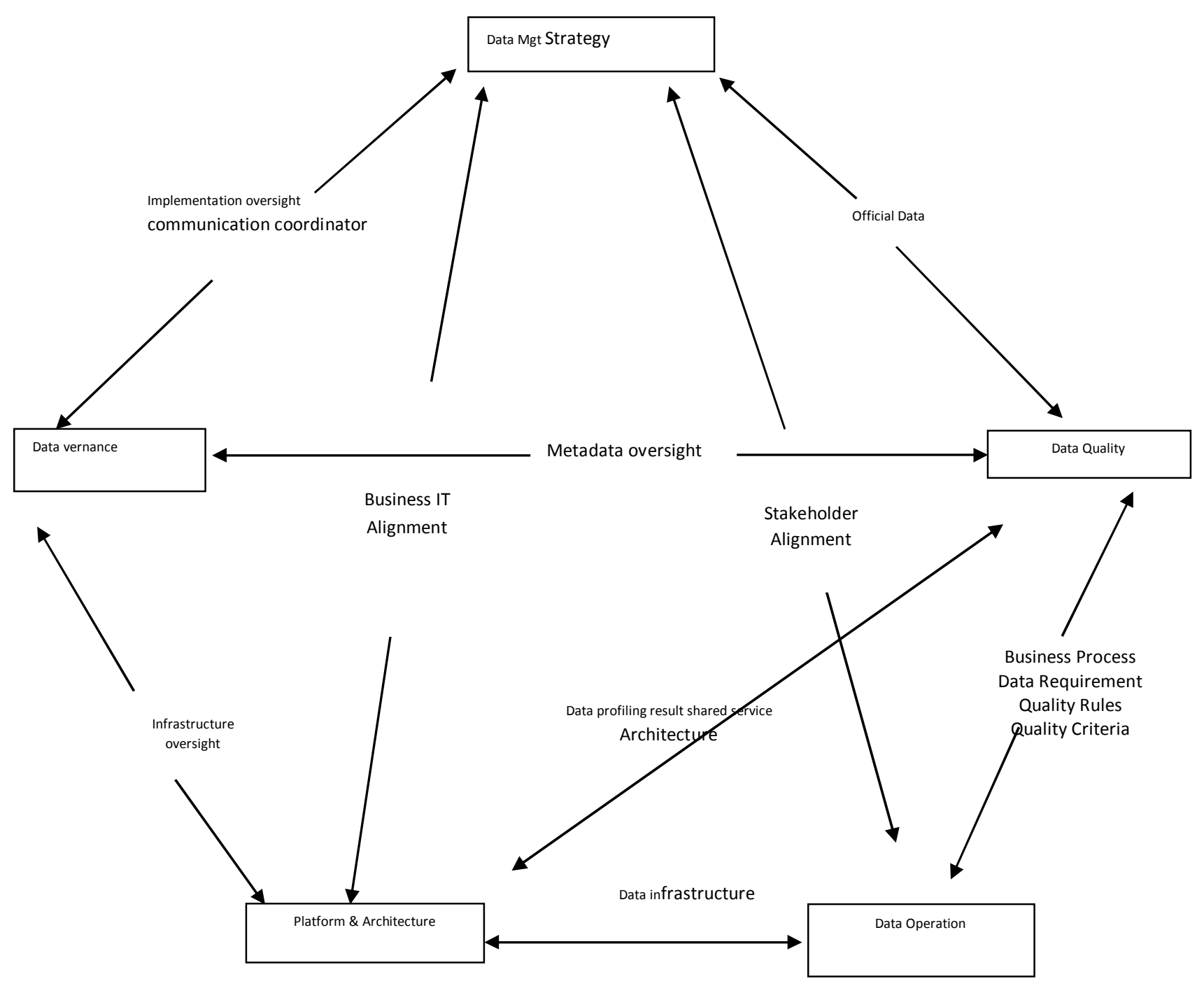

Source; CMMI Institute, 2017.

This research work is by no means suggesting that this model is the only model that is capable of solving the data management problem in Nigeria. Other models may also be acceptable depending on predetermined factors. Other models similarly suggested include; the business model, data management maturity model, Network model, etc.

\section{Uses of integrated data system in an economy}

The benefits of a integrated data management system are listed below to includes; [10]

-Reduction in duplicated work

-Inspiration for new/continuation research and funding

-Basis for knowledge extraction from aggregate data

- Greater transparency of research

-Improved basis for validation

-Obviating the need for re-collection and generation

-Providing basis for reliable data citation

-Increased scholarly output. 


\section{MATERIALS AND METHODS}

The study adopted a survey design using cross-sectional data collected from different business outfits in Edo State, a survey design is adopted in the study because, since all members of the population of interest cannot be reached survey design makes it possible for making judgement on the sample that was drawn using representative sampling procedure. Equally, diverse businesses constituted the entities of our study.

The researchers used systematic random sampling were the local Governments in Edo state is divided into different units and respondents randomly selected within each unit. This allowed the researchers' to add a degree of systemization into the process which made the process more desirable.

The instrument for data collection used in the study is the structured questionnaire that is designed by the researchers and administered to the respondents after testing the instrument for validity and reliability

The method of data analysis used in the study is the chi-square test which was computed by using the SPSS statistical package

\section{RESULTS AND DISCUSSION}

The results of the data analysis conducted using the $x^{2}$ is presented in table one and table two below.

Table 1

\begin{tabular}{|l|l|l|l|}
\hline & Value & df & $\begin{array}{l}\text { Asymp. Sig. } \\
\text { (2-sided) }\end{array}$ \\
\hline Pearson Chi-Square & $60.373^{\mathrm{a}}$ & 4 & .000 \\
Likelihood Ratio & 68.935 & 4 & .000 \\
Linear-by-Linear & 8.141 & 1 & .004 \\
Association & 200 & & \\
N of valid Cases & 200 & & \\
\hline
\end{tabular}

a. 0 Cell $(0 \%)$ have expected count less than 5 . The minimum expected count is 11.88

Source; Field survey.

Table 2

\begin{tabular}{|l|l|l|l|}
\hline & Value & df & $\begin{array}{l}\text { Asymp. Sig. } \\
\text { (2-sided) }\end{array}$ \\
\hline Pearson Chi-Square & $93.428^{\mathrm{a}}$ & 4 & .000 \\
Likelihood Ratio & 129.074 & 4 & .000 \\
Linear-by-Linear & 35.632 & 1 & .000 \\
Association & & & \\
N of valid Cases & 200 & & \\
\hline
\end{tabular}

a. 0 Cell $(0 \%)$ have expected count less than 5 . The minimum expected count is 15.12

Source; Field survey.

From the results of our analysis which is presented in table one and table two above one can observe that Pearson's chi-square of 60.373 with a degree of freedom of 4 shows that our analysis is significant at $5 \%$ critical level thus indicating that the respondents agree that there is the need for an integrated data management in Edo state and by extension the whole Nigeria.

To further confirm the results of our analysis the same question was reframed and administered to the same subjects and the answer as presented in table two with a Pearson's chi-square value of 93.428 with a degree of freedom of 4 shows that our analysis is significant $5 \%$ critical level indicating again that respondents overwhelmingly agree that there is the need for an integrated data management in Edo state and by extension Nigeria.

\section{CONCLUSION}

Ensuring that economic data and information is accurate and reliable have long been recognized to be a direct contributor to good organizational performance leading to better economic opportunities for both government and business enterprises. To statistically analyse the need for an integrated data management in Nigeria the researchers 
randomly collected data from different business outfits within Edo state for the study, results indicated that there is the need for an integrated data management in Nigeria given the fact that with a well formulated integrated data management system, data management will be much cheaper and more acceptable to all entities operating in Nigeria, this will in turn lead to multiple opportunities for improvement.

\section{ACKNOWLEDGMENT}

The authors of this study did not receive funding from any organization or institution in the course of the research.

\section{RECOMMENDATIONS}

Based on the exposition of our work the following recommendations are proffered.

Nigeria should immediately set-up an effective and efficient integrated data management system to enable all economic and business agent obtain accurate data and proactive information for their operations.

Both economic and business entities should contribute, encourage, trust and make use of the data and other information assembled by the CIDM.

Research and other scholarly output of research institution, other academic institutions, business intelligence information should form a pivotal point of the data feed into the CIDM, such activities should not be left in government hands alone as such a scenario may be susceptible to political and other forms of manipulation.

Data security should form an integral part of the established CIDM to be implemented. Since data breaches have the greatest potential to seriously harm business and economic entities, protecting sensitive data requires diligence, strong security solution as well as constant investment to keep current with the latest threats to data crimes.

\section{REFERENCES}

[1] J. Curry. 'The data Advantage. How accuracy creates opportunity," An Experian QAS Research Report 2013. Accessed on $5^{\text {th }}$ Jan. 2017, from; www.experian.co.uk.

[2] T. Burniston. "Data Governance: A regulatory and Business Imperative." ABA Banking Journal. Nov/Dec 2015 edition. Accessed on $5^{\text {th }}$ Jan. 2017 from www.nxtbook.com.

[3] M.A. Obomeghie. "Analysis of Socio-economic statistics". JES publishers, Auchi-Edo State, Nigeria.2015. pp 123205.

[4] M Darlington. "Managing Engineering Research Data at the University of Lincoln": Part 2 of 2 ( $2012 b$ Presentation). Accessed 30 Jan. 2017from: http://www.slideshare.net/ulcerd/erim-redmmed-and-orbita

[5] The DAMA guard to the data management body of knowledg. (2009). Accessed on $5^{\text {th }}$ January 2017 from www.academia .edu.

[6] Tech target "Data management". 2016 edition, Accessed on $5^{\text {th }}$ Jan. 2017, from: http/searchdatamanagement.techtarget.

[7] M.H.Buenette, S.C. Williams, and H.J.Imker. "From plan to action: successful data management plan implementation in multidisciplinary project," Journal of eScience librarianship.(5)1. E1101. http://dx.doi.org/10.7191/jeslib.2016.1101.

[8] N Manamley, S. Mallett, R.M. Sydes, S. Hollis, A. Scrimgeour, H.U. Burger, and H.J, Urban. :Data sharing and the evolving role of statisticians". BMC Med Methodol 16 (2016 suppl 1 ) 75. Doi - 10 11ab/512874 - $016-0172-9$ PMID. PMC4943485.

[9] CMMI. "Data management maturity". Dec. 2016 report. Accessed 28 February 2017, from: http://cmmiinstitute.com/data-management-maturity.

[10] M. Darlington. "Managing Engineering Research Data at the University of Lincoln: Part 1 of 2 (February, 2012a Presentation). Accessed on $15^{\text {th }}$ Jan. 2017, from: http://www.slideshare.net/ulcerd/erim-redmmed-and-orbita

Cite this Article: Obomeghie MA, Bello AO and Idris A (2017). The need for an efficient Integrated Data Management (IDM) system in boosting economic opportunities in Nigeria: Empirical evidence from Edo state. Greener Journal of Social Sciences, 7(5): 060-066, http://doi.org/10.15580/GJSS.2017.5.112217173. 


\section{APPENDIX I}

\section{QUESTIONNAIRE}

Please tick $(x)$ or fill accordingly

Section A: PERSONAL INFORMATION

Sex? Male ( ) Female $\quad$ ( )

Marital Status. Single ( ) Married ( ) Widow ( ) Divorced ( ) others specific ......

Age of respondents. $\quad 23-27(\quad) 28-32(\quad) \quad 33-37(\quad) 38-42(\quad) 43-47(\quad) 48-52(\quad)$ above $53(\quad)$

Level of schooling attained. Primary school（） Secondary School（） Higher Institution（ ）

Occupation. Non -Government employed ( ) Self-employed ( ) Government employed ( ) other specify .........

How long have you been in your job? Less than 3 years $(\quad) \quad 3-5$ years $(\quad$ ) More than 5 years $(\quad$ )

What is the position in your organization? Director $(\quad)$, Management staff $(\quad$ ), senior staff $(\quad)$, Trainee $(\quad)$

Section B: Adaptation and usage of integrated data management

\begin{tabular}{|l|l|l|l|l|}
\hline S/No & \multicolumn{1}{|c|}{ Agree } & Undecided & Disagree \\
\hline 1. & $\begin{array}{l}\text { We use date management in our } \\
\text { organization }\end{array}$ & Freq & Freq \\
\hline 2. & $\begin{array}{l}\text { There is a data officers in our organization } \\
\text { organization is linked to all units } \\
\text { orf my }\end{array}$ & & & \\
\hline 4. & $\begin{array}{l}\text { There is a central data unit in my } \\
\text { organization }\end{array}$ & & \\
\hline 5. & $\begin{array}{l}\text { Since the introduction of data } \\
\text { management in my organization there is } \\
\text { improvement in our services }\end{array}$ & & \\
\hline 6. & $\begin{array}{l}\text { The introduction of Data management in } \\
\text { my organization has led to better services } \\
\text { for our customers }\end{array}$ & & \\
\hline 7. & $\begin{array}{l}\text { The introduction of Data management in } \\
\text { my organization has led to increase of our } \\
\text { customers }\end{array}$ & & \\
\hline 8. & $\begin{array}{l}\text { The introduction of Data management in } \\
\text { my organization has led to increase in } \\
\text { patronage }\end{array}$ & & \\
\hline $\begin{array}{l}\text { We share our data with government and } \\
\text { other non-governmental agencies. }\end{array}$ & $\begin{array}{l}\text { We often receive information from } \\
\text { governmental and non-governmental } \\
\text { agencies }\end{array}$ & & \\
\hline 10 & & & \\
\hline
\end{tabular}

